Article

\title{
Theodramatic Rehearsal: Fighting Self-Deception through the Dramatic Imagination
}

\section{Brett Vaden ${ }^{1,2}$}

1 Southern Baptist Theological Seminary, 2825 Lexington Road, Louisville 40280, KY, USA

22939 Rio Rita Avenue, Louisville 40220, KY, USA; E-Mail: brettvaden@gmail.com;

Tel.: +1-502-435-4646

Received: 20 December 2013; in revised form: 31 January 2014 / Accepted: 17 February 2014 /

Published: 3 March 2014

\begin{abstract}
This paper seeks to appropriate the insights of dramatic theology for Christian psychology and soul care. According to Kevin Vanhoozer, Scripture is the 'script' for human beings' fitting participation in the acts and deeds of God in the world (i.e., 'theodrama'). Keeping with this dramatic paradigm, the author will explore what 'rehearsal' might entail by drawing from a branch of psychotherapy called 'psychodrama.' The main question to be addressed in this appropriation of dramatic theology is, "How might dramatic rehearsal combat self-deception?” The author will only begin to answer this question, but in the attempt it is hoped that further reflection and clarity will be induced.
\end{abstract}

Keywords: self-deception; psychodrama; theodrama

\section{Introduction: Dramatic Action}

"Then Buttercup was gone, out of sight.

Westley took a breath. He was aware of the score of soldiers starting to surround him, and probably he could have made a few of them perspire for their victory.

But for what point?

Westley sagged.

"Come, sir." Count Rugen approached. "We must get you safely to your ship."

"We are both men of action,” Westley replied. "Lies do not become us.,” [1]

This scene from The Princess Bride provides audiences with one of its memorable quotes. Shortened slightly in Rob Reiner's film adaptation, it follows: "We are men of action. Lies do not 
become us.” To the honorable Westley, there is something about lying that does not befit a man of action. Men of action do not resort to lying; it is unsportsmanlike. Rather, these men take action.

According to the Bible, human persons do not develop into full humanity unless they assert their will: "Be fruitful and multiply and fill the earth and subdue it and have dominion over the fish of the sea and over the birds of the heavens and over every living thing that moves on the earth" (Gen. 1:28). If this command is foundational to full human life, then action is required to mature as a human. According to one Christian psychologist, human agency entails several qualities that are essential to development: rational-linguistic ability, a high degree of self awareness, the power to reason, responsibility, and imagination [2]. Humans are not simply objects meant to be acted upon, but have their telos as actors who imagine possibilities, deliberate upon those possibilities, make decisions, act, and bear responsibility—all in full conscious awareness.

\section{The Theodrama}

The analogy of drama can be a helpful metaphor to understand the full flourishing of human beings as agents, or actors. One theologian who has greatly capitalized upon this analogy is Kevin Vanhoozer, who describes God's action in the world as 'theodrama' [3]. The God of Scripture created the world, sustains it, and is redeeming it. From the beginning, he has actively directed every course of action in the universe according to his plan. His action was revealed preeminently through the history of Israel, yet from the origins of man God has revealed himself as the Creator and Lord of every person, including those outside Israel. Through the descendants of Abraham, God has extended his blessings to the whole world. In the Old Testament, this outreach was dominantly worked out in a centripetal way, drawing the Gentiles into the fold of Israel. After the coming of Christ, however, Father, Son, and Holy Spirit have turned the focus outward, so that the Word of God might ripple out in a centrifugal wave to all the nations.

In the Bible, the acts of God are conveyed in a narrative form. Scripture frames God's actions in Israel and the world as a story. Of course, narrative is one specific genre employed throughout the sixty-six books of the Bible. Large portions of the Old Testament are story forms (e.g., stories of Abraham, Jacob, and Joseph), and in the New Testament the four gospels provide biographical narratives of Jesus' life. According to a canonical perspective, however, the entire sweep of God's activity in the world may be seen as one grand story. His relationship with the nation of Israel, according to Klyne Snodgrass, is summarized in several of Jesus' parables: the wicked tenants (cf. Matt. 21:33-46), the wedding banquet and the feast (cf. Matt. 22:1-14), the barren fig tree (Luke 13:6-9), and the two sons (Matt. 21:28-32) [4].

Moving from story to drama as a metaphor for God's activity might seem like a small shift, but there is a significant difference between them. Both mediums are about action. As Aristotle makes clear in his Poetics, narrative and drama are forms of mimesis, or the imitation of action through its organization as plot. The key difference is that while narrative tells us the action, drama shows it. At first, again, this difference may seem insignificant, unless one consents to viewing the disparate texts of the Bible as a unified canon.

Scripture does not take the form of drama, but as a written compilation of books, which include many generic forms. It would seem that the message of the Bible is limited to a form that can be told, 
but not shown. Or is it? While it is true that the Bible comes in a written form that can be read or heard, it is also the case that the Bible can be lived and seen. There is a sense in which Scripture is delivered in a textual medium, and yet there is also another sense in which it is delivered in a dramatic medium. What is the dramatic medium?

Scripture's authors all seem to assume that God has entered into the world and acted in a way that can be perceived by human beings. Vanhoozer uses the term 'theodrama' to capture this idea: “Theodrama is a matter of God's taking the initiative to make himself known to others, of God's parting the heavenly curtain in order to reveal and redeem” ([5], p. 7). The theodrama is God's interaction with human beings through speech and deed, with the climatic turning point being the incarnation, life, death, resurrection, and ascension of Jesus Christ. Vanhoozer says, therefore, that the medium of the theodrama is "living persons in dialogical interaction and covenantal relation” ([5], p. 7). The theodrama is recorded in the Biblical text, but that does not mean the theodrama has ceased to play. God still interacts with human beings, indwelling and empowering many to know him and participate with him in his action. As Vanhoozer would put it, human history is now somewhere between the climactic act (Christ's cross and resurrection) and the curtain call (the Last Judgment) of the theodrama.

Viewed in this way, the Bible is not only a record of previous acts in the theodrama, but also a script for its continued performance. Vanhoozer says, "The Bible is the authoritative account of the mighty acts of God in the past. As such, it is a dogmatic text that regulates Christian belief. But it also regulates Christian behavior, prescribing - which is to say, directing by writing - the way of Jesus Christ” ([5], p. 8). The Bible is thus the 'script' for a human being's fitting performance in the theodrama.

Being a script would imply that Scripture has instrumental value as well as intrinsic value [6]. Scripture is thus a script that directs actors in the theodrama. The Law given in the Torah, the promises and warnings of the prophets, the expressive lyrics in the Psalms, the assertions in Paul's letters, and the declarations given to individuals and groups throughout the Bible are all examples of understanding Scripture as the communication of various speech-acts. Drawing from speech-act theory, one might see that Scripture does things with its words besides relaying propositions, or assertions. One way the words (locutions) function (illocutions) is to command people to live in its way, or to perform according to its direction. Scripture's words can be understood to have value in themselves, but they might also have instrumental value by providing direction for fitting performance in the theodrama.

Theologians like Vanhoozer within the Judeo-Christian tradition have maintained that, despite Scripture's usefulness as God's script, human beings fail to perform as the 'script' directs. People do not show up as 'men of action,' as idealized by Westley in William Goldman's fantasy story. Rather, like Count Rugen, lies become them. Authentic action is negated by self-deception. Self-deception, it will be argued, impedes an individual's participation in God's drama by corrupting the mind, heart, and will through the imagination. On the other hand, self-deception can be attacked and overcome to some degree, and this confrontation happens in the same faculties—mind, heart, and will—through the imagination. In the following section, the author will briefly define self-deception and then explore its effects on the mind, heart, and will. 


\section{Self-Deception}

Self-deception is a concept that has received ample consideration. It has been discussed across various disciplines, especially psychology, ethics, and theology. In psychology, self-deception is often discussed in terms of defense mechanisms, or defensive activity [7]. Psychology has looked at the motivations for self-deception and clarified the means for hiding these motivations and desires through defensive structures. For example, one desires affection from others, but he has perceived from childhood experience that affection can be won or lost, depending on how he appears to significant others, such as his parents. If he does something wrong, he will not be loved. When, therefore, something threatens his sense of being loved or accepted, he defends against the negative feeling that comes from such a threat. How does he defend himself? By denying or ignoring negative experiences with defensive measures, such as hiding, avoidance, blame-shifting, or projection. Defensive activity can reveal a deep need one has to affirm his goodness and worth. One may turn to self-deception when he perceives his sense of worth is in jeopardy.

Ethics has pointed to self-deception as an absurd but nevertheless real experience. Self-deception is absurd because it involves double-mindedness in the person. On the one hand, a person knows that something is the case ("These Jewish people are being eradicated and I am standing by"), and yet, on the other hand, he pretends that this point is irrelevant or inconsequential ("I am doing nothing to harm anyone”). Self-deception is lying to oneself in order to serve a particular interest. Though there is plenty of evidence towards one course of reasoning, it is supplanted by a contradictory false belief in order to protect a desire connected with the false belief [8].

Lastly, theologians have often pointed to the root of self-deception in the sinfulness of humanity. One employs self-deception to maintain a false belief about oneself and God. To do so one must disconnect from God (i.e., tell oneself God does not exist) or become God (i.e., tell oneself he or she is God). John C. Knapp says, "The self-deceiver rejects the God-relation and the truth that it may reveal. Self-deception often entails suppressing or evading knowledge of the truth in order to maintain false beliefs that support a desired self-image” ([9], p. 17). Again, self-deception arises out of a need to see oneself in a certain way. There is a deep desire for value, significance, and worth; because of sin, however, one's value is not received from God, but sought outside him. Theologians call this sinful desire for self-worth 'pride.' Knapp says:

Theologically speaking, self-deception is of deeper significance than the mere acts of holding conflicting beliefs, avoiding unwanted information, or protecting self-esteem. To attempt to be what one is not, to

willfully believe a falsehood about oneself or one's situation, is to attempt a deception before God who is the truth. Self-deception, therefore, is the handmaiden of pride ([9], p. 18).

At the root of self-deception, therefore, lies an inclination of the will that mutates one's desire for self-worth into the sin of pride.

Let us now consider how self-deception, motivated by pride, might affect the mind. Intellectual knowledge of the theodrama is required for fitting performance, according to Vanhoozer. Knowledge, however, can be distorted. An actor can memorize the script, but if he or she interprets it incorrectly, performance will be poor. In order to misconstrue the theodrama or one's place within it, self-deception hijacks the mind and uses reason in order to serve its sinister purposes. Of course, self-deception is not 
rational, but the self-deceived person employs a veneer of reason to justify his underlying motive [10]. While one might assume that the solution for a self-deceived mind is to present it with better thinking (e.g., cognitive therapy), it is not primarily the soundness of one's reasoning that is the root issue, but the underlying motive or interest being protected. The content of one's ideas, whether it be sound or not, is only the surface issue - a shield that can shift from here to there, blocking rational attacks — that deflects one from its real function, which is to deceive oneself. The self-deceived mind does not even consider that it needs to be intellectually corrected; in fact, it heavily arms itself against any such notion! In the Bible, the archetypal character for this phenomenon is the Pharisee. For the typical Pharisee presented in the gospels, the truth is used to hide from truth. Merold Westphal demonstrates how the Pharisees and the rich young ruler used the content of their ideas to hide the function: "It was the function and not the impeccable content that separated them from the kingdom. Orthodoxy enabled the young man not to notice his idolatry and the Pharisees to be inattentive to their self-righteousness" ([11], p. 14). Human intelligence is a powerful gift, but it would seem that the greatest mind can easily serve self-deception and thereby foil one's participation in God's purposes in the world.

The emotions would also seem to be required for fitting performance, but human affectivity can be distorted. Jonathan Edwards faced this problem during the revival movements of the Great Awakening, in which it was difficult to tell whether emotional fervor was a true mark of spiritual affection or of self-deception [12]. If one's intellect can manipulate thoughts, even very true thoughts, in order to deceive oneself, a person can use his emotions in a similar way. Dietrich Von Hildebrand has illuminated the heart's complicity in self-deception by describing how powerful, deeply felt emotions can enable one to confuse enthusiasm about a virtue with its actual possession: "[...] the illusion consists in mistaking the intensity of the enthusiasm for a sign that one already possesses the virtue one is enthusiastic about. Because one lacks spiritual sobriety, one fails to distinguish two strata of personal reality, namely enthusiasm for an attitude or virtue and the real possession of that virtue” ([13], p. 52). An example of such self-deception appears in the incident between King David and Nathan (cf. 2 Sam. 12). Nathan's story of the poor man and his lamb ignites David's heart to feel deeply, or enthusiastically, as the text says, “Then David's anger was greatly kindled against the man, and he said to Nathan, "As the LORD lives, the man who has done this deserves to die” (2 Sam. 12:5). What cannot be denied in this incident is the validity of David's emotion. His anger was valid, for he rightly discerned the injustice done to the poor man. Anyone who does not get angry hearing such a story is probably in a worse position than David. As Von Hildebrand says, "The enthusiasm may be genuine and is as such a first step which may lead to real obedience. It is even the basis for the acquisition of this virtue” ([13], p. 52). If David had not gotten angry, there would have been no bridge to Nathan's real point: "You are the man!” Yet, the fact that David could get so angry_and rightly so in a sense-serves to show how David was self-deceived in his heart. He could feel an enthusiastic animosity towards injustice done by someone else, but what about the injustice he himself committed? If not for the spiritual sobriety of Nathan's indictment, David's fiery heart would have cloaked his own sin and subverted his fitting performance as King of God's people.

Like the mind and heart, the will's facility in the theodrama can also be negated through self-deception. Just as a self-deceived person makes use of the mind's ideas and the heart's affections, so he can manipulate the will's volitions. One might consider what we have said so far and reply, 
"Well then, it seems the thing to be done is to tell the truth. One must will himself to honesty! Authenticity! One must commit to being true in his thoughts and emotions.” This thinking overlooks the fact that the will can also be employed in self-deception. Stephen Crites might offer this rejoinder to the suggestion that one can will himself to honesty: "But from the fact that self-deception is "in some sense" willed, it does not follow that you can therefore overcome it by a sheer teeth-gritted act of will” ([14], p. 110). A person may have a fully operational will, and he may employ his will expeditiously to accomplish enormous feats, yet all to deceive himself from his will's deep-seated corruption and disobedience in the sight of God. Consider King Saul. Instead of obeying God's command to destroy all the spoils of the battle, he keeps the best. When confronted with his sin, he disowns his fault by offering sacrifices to God out of those spoils. He does not passively stand by; no, he acts. Yet, his act of will was a feigned obedience, a deceptive gesture, which led to his dismissal from an active role in God's theodrama.

From this discussion, one may make two inferences. First, self-deceptive behavior is characterized by some degree of unconsciousness. The Pharisees were unconscious of the way they used their orthodox minds to mask their heterodox hate for the Son of God. David was unconscious of the way he used his heartfelt anger to reinforce his self-righteousness and suppress his guilt and shame. Saul was unconscious of the way he willed to serve God in order to cover up his disobedience. Peter Sedgwick pithily summarizes our confounded situation: "Human action is not a series of responsible decisions taken by self-aware people in control of their lives” ([15], p. 404). Self-deception disables self-awareness and responsibility, which are integral to mature human agency. One cannot perform fittingly in the theodrama if he is unconscious of his own self. Or, to state it positively, to rightly play one's part in the theodrama one must become more self-aware instead of self-deceived and unconscious.

Second, self-deception is not characterized by total unconsciousness, but by a 'willing suspension of disbelief' [11]. This phrase was coined by Samuel Taylor Coleridge to describe the aesthetic experience of entering a world created in the imagination [16] ${ }^{1}$. J.R.R. Tolkien calls this a 'secondary world', distinguishing it from the primary world not in terms of real versus unreal-since what one imagines is by no means less real just because it happens inside the mind-but in terms of actuality versus perception [17]. In other words, self-deception works inside a secondary world formed by the imagination that affects how the primary world is perceived. In a work of fantasy like Tolkien's The Lord of the Rings, in order for a reader to enter Middle-earth he must willingly suspend his conscious awareness of the separation between primary and secondary reality. In order to imagine the 'subcreated' (Tolkien's word) world where hobbits and elves exist, one must break his attention away from whatever else he could be thinking about and direct it wholly—with mind, heart, and will—-to participate in the imaginative construction and apprehension of that world. Of course, Middle-earth is not one's primary world. In order to get there, one must suspend his disbelief of it. The point is, however, that when one arrives, Middle-earth takes on the attributes of reality in his perception; the towers of Minas Tirith are seen and the falls of the river Anduin are heard. One's mind, heart, and even will become captive to that secondary world formed by my imagination. As Tolkien argues in "On

1 By "imagination" is meant the faculty of forming mental images or concepts that are not actually present to the senses. While the imagination is a faculty of the mind, it has a special function that distinguishes it from other mental faculties: to form images that are not actually present to the senses. 
Fairy Stories," the secondary world can affect how one perceives the primary world if one accepts what it offers to tell about reality (e.g., that evil is real and terrible, but good will ultimately triumph) [17]. In a similar way, self-deception takes one captive to a distorted perception of reality by means of the imagination: false images of oneself and the world are formed in the mind because one decides to suspend belief in what is actually true.

The thesis of this paper is that in order to combat self-deception the imagination must be re-oriented to reality through a willing suspension of disbelief. Rather than believing in a distorted perception of reality, a person desiring to perform in the theodrama must allow his mind, heart, and will to be captured and persuaded by an imaginative re-construction and re-apprehension of himself and the world. For the remainder of our time, we will consider how one can suspend his (false) beliefs and entertain a new perspective that invites alternate beliefs through an appeal to his reason, emotions, and desires. First, we will observe how the imagination works with the mind, heart, and will to either refute or confirm one's beliefs about oneself and the world. Second, we will ask how we might integrate Scripture, or "the script", with a therapeutic tool known as psychodrama in order to reconstruct the secondary world of the imagination and transform one's experience-mentally, emotionally, and volitionally — of the primary world. This process we will call theodramatic rehearsal. It will be suggested as one possible method for scaffolding the construction of the secondary world in the imagination. Finally, we will draw some conclusions for further study.

As has been said, the mind, heart, and will are susceptible to the machinations of self-deception through one's use of the imagination. At the same time, if self-deception is understood as a form and manifestation of sin, it is therefore parasitical; like sin, the only way it can operate is by distorting something that is useful, good, and intended for human maturation: imagination. Thus, the imagination should not be equated with self-deception or sin; rather, it is the means for self-deception. The imagination is a useful instrument. What is its use, good or bad?

The instrumental use of the imagination is that it can either confirm and reinforce beliefs, or it can discredit them. A person may hold certain beliefs about the world, but he can suspend those beliefs, even if just for a moment, because his imagination allows him to entertain alternate beliefs. To a class of college freshmen, a clever, charismatic professor may winsomely and persuasively propose ideas about the world that invite a willing suspension of long-held beliefs or assumptions in the minds of his students. The imagination allows one to entertain a new perspective-contradictory to one's ownthrough a persuasive appeal. If this appeal is strong enough, then one's former beliefs may be disavowed and cast aside. On the other hand, the appeal may be too weak, and then the imagination continues to align with the old way of seeing. Imagination is like a projector that displays possible images, which either strengthen beliefs/assumptions or weaken them. While the imagination can be used to construct or build up a false belief it can also deconstruct it. The next question is how it does so.

Looking back at the example of David and Nathan above (the one successful case), we can see the imagination working with the heart, mind and will; specifically we see how it allowed David to enter into a narrative willingly so that he was able to think, feel and act in a certain way. As Nathan told the story, David imagined it. David willingly participated with the narrative by allowing himself to "see" the characters and follow their actions with his mind's eye. One can be reasonably sure of this fact without having access to David's mind for two reasons. First, we ourselves can imagine the story as Nathan tells it, so we can infer that David could as well. Second, David evidences by his response that 
he has followed and understood the story: “Then David's anger was greatly kindled against the man, and he said to Nathan, "As the Lord lives, the man who has done this deserves to die, and he shall restore the lamb fourfold, because he did this thing, and because he had no pity” (2 Sam. 12:6). David's imagination cooperated with the story in a way that allowed him to construe its events in a certain way, feel emotion, and act in response. The text focuses first on the emotion, telling us that David felt great anger toward the rich man. The text then says that David reacted by pronouncing a judgment: the rich man should die and restore the lamb fourfold. One could infer the reasons for David's judgment, but the text tells plainly that it was because the rich man "did this thing, and because he had no pity." David was thus affected in his heart, mind and will by virtue of his imagination, which allowed him to enter into Nathan's story. He believed willingly what Nathan related to the degree that he was moved to think, feel and act in a certain way, namely, in a way fitting to the story. He responded fittingly because he construed the story for what it was, an instance of injustice, i.e., "he did this thing," and cruelty, i.e., "he had no pity." He responded fittingly because he felt a fitting emotion in response to the injustice and cruelty: anger. And he responded fittingly because he pronounced judgment—David's role as king required him to act as judge over his people's affairs. There seems to be no hesitation on David's part to participate in the ‘secondary world' projected in Nathan's story.

One might wonder why David's imagination cooperated as willingly as it did. First, Nathan was a respected voice to David. The reader is told that Nathan was a prophet of the Lord who had come to David before, and moreover David heeded Nathan's words as the very word of the Lord (2 Sam. 7:3-29). Nathan bore a high degree of credibility with David that was likely a strong factor in his willingness to cooperate imaginatively. A second likely factor in David's willing participation is related to his deep concern for justice and the value he placed on kindness and compassion. His reason for condemning the rich man was based on the injustice he committed and the lack of pity he showed. The value David placed on justice and pity made him acutely attuned to the story; his values influenced his seeing. According to William Wood, Blaise Pascal saw a close link between what one values and the way one sees: [T] here is a direct relationship between the way we value beloved objects and the way we see them, which affects the beliefs we form about them. ([18], p. 378). David valued compassion, and so he was touched by the poor man's suffering at the hands of his wealthy neighbor. In other words, the story mattered to David because it dealt with concerns close to his heart. Yet a third factor in David's imaginative cooperation is the story's logic and simplicity, which allowed him to easily and quickly construe its meaning. The story takes up five sentences in an English translation; it has two main characters, and after briefly comparing the rich man to the poor man and describing the poor man's affection for his ewe lamb, the story delivers the main action in one sentence: "Now there came a traveler to the rich man, and he was unwilling to take one of his own flock or herd to prepare for the guest who had come to him, but he took the poor man's lamb and prepared it for the man who had come to him” (2 Sam. 12:4). There is little chance that one hearing this clear, concise narrative could misconstrue it. Surely David tracked along with it as well as any listener could, for the way he construed it facilitated an emotional and volitional response. Robert Roberts defines emotions as 'concern-based construals,' meaning that emotions flow out of the way one construes his experiences in light of his core concerns [19]. David's concern for justice and compassion worked in tandem with his construal of the story, so that he responded with anger towards the rich man, whom David willingly condemned to certain punishment. 
Note that although Nathan had finished the story, David's imagination continued to work. David did not stop using his imagination when the story ended; rather he kept constructing the story so that he could reach a conclusion. Here we see that Nathan had not provided David with a self-enclosed narrative but an open-ended one, which invited a further response. And David did respond, with emotion and decision, while still using his imagination. David used his imagination to finish the story with a fitting ending: punishment for the rich man and payment for the poor man. The point here is that the imagination can do more than entertain a narrative; it can cooperate in the construction of the narrative.

Further, when a person cooperates in the making of an imaginative construct, that construct in turn has reciprocal effects on the will [14]. David not only willingly entered into the story through his imagination, but his imagination cooperated in the story's construction so that he was moved to action, becoming himself one of the story's agents. Using Tolkien's terminology, one could say that David's willing participation in the 'secondary world' of the story led to effects in his 'primary world.' This operation accords with the function of the imagination described above: it can either construct and reinforce beliefs, or it can dismantle and discredit them. The imagination builds a secondary world in the mind that may be believed in, and if belief is achieved, willing action follows. Action demonstrates belief_-belief that rests on an imaginative construct.

For David, his imaginative engagement in a story allowed him to temporarily disengage from his self-deception and lower his defenses even to the point that he unintentionally condemned himself. For a fleeting moment, a new imaginative construct released David from his old, false imaginative construct. This phenomenon demonstrated in David's life is not unique. For many people, the imagination is daily employed to either construct a false view of the self and the world or to construct a true view. For example, Crites describes how a person might imaginatively support the perception that he is a scholar: "If I am a scholar, I have books strewn on my desk and paper in my typewriter with a few lines typed on it, my pipe is lit, my lips are severely pursed, and an apologetic intruder could never guess how much of the afternoon I have spent pursuing sexual fantasies and muttering venom against my enemies” ([14], p. 121). Such an imaginative ability can veer a long way off the direction outlined in God's script, for it works to corrupt the heart, mind, and will. On the other hand, if the imagination was created with a good purpose, then it can be used to promote fitting performance in the theodrama. In David's case, one imaginative construct held him captive to self-deception, while another-instigated by Nathan-was able to release him. In other words, prior to his encounter with Nathan, David imagined himself to be innocent. Clearly this imagined construct was false. Yet by suspending his false construct and engaging in a new and different one told by Nathan, David was able to escape from his false self-image and receive the truth about himself: he was the guilty man who deserved punishment.

In David's life, as in the lives of many individuals, the imagination had an effect on his identity, or the way he saw himself. A person constructs the secondary world with himself as a player in it; he has a role in the drama of his imagination. One crafts a world that usually reinforces his identity. As seen with David, that identity can be either false or true.

In the construction of identity, the imagination works off of the suggestions of others outside oneself. Other people add bits and pieces to one's imaginative self-construct, like a mosaic. Harter describes the construction of one's self, or identity, as a process that involves the individual as well as significant others in his or her life [20]. Parents erect a scaffold that supports a certain construct of a child's identity. On a larger scale, social narratives feed one's own auto-narrative, aiding the formation 
of identity [21]. The individual person fashions his own self-image, but not without enlisting others in the project. In David's case, there may have been many people supporting his false self-image, such as servants and counselors. Nathan however, refused to support it, and his subversive influence was enough to break David's false self-image.

Because self-deception co-opts with the imagination, and, as we have just noted, the imagination is influenced by others outside oneself, the social dimension of self-deception must be acknowledged. One's self-deception is perpetuated (or hindered) by other people as well as by oneself. Beguiled and allured by one's ideal (and false) self-image, he seeks as many ways as possible to protect and nurture it, so as to further blind himself from the truth. One way to do so is through the support of others: "In order to deceive myself I must enlist the complicity of others, however passive or unwitting their complicity may be” ([14], p. 124). If one can garner approval for his self-image from someone else, then that self-image is so much more secure. An idiosyncratic illusion is exchanged for a verified reality. In the case of a newlywed husband seeking his wife's approval, he may look for it in various forms, but perhaps none simpler than spoken praise. If he receives it, his self-image is bolstered, but if not, it is threatened. Depending on her response, her husband's imaginative self-construct might be met with approbation and support or with confrontation and resistance. With a word she can promote his false self, and with another she can call it into question. Therefore, just as self-deception is a social project, so is its exposure.

To fight self-deception, one must address his or her imagined identity as both an individual and social construct. In a moment, we will look at a social context (i.e., psychodrama) for the imagination's reorientation according to the theodrama. It is necessary to recognize that reorienting the imagination in order to reconfigure one's identity cannot be done solo. Identity begins to form in childhood, taking on the suggestions and scaffolding of others. If identity is in need of reformation, it will require outside help: "Because the imagination is socially constructed, reorienting the imagination requires something like a massive program of counter-habituation comparable to becoming a native member of a wholly new society” ([18], p. 380). For Christians, that new society is the Body of Christ (Eph. 4:12), or the New Self (Eph. 2:15). The ultimate locus of a Christian's identity is found in God through Jesus Christ [22]. It is thus as a member of Christ's body that a Christian must reconstruct his self-image [2]. To fight self-deception, one must consider who he or she is as a particular member of a universal body. Or, to use the language of the theatre, self-deception must be addressed with an awareness of one's role within the entire performance of the theodrama. Drama turns out to be an apt means for self-insight, as contemporary scholars have already begun to explore [23].

\section{Psychodrama}

Psychodrama, as a recognized form of psychotherapy, was introduced to psychology in the early 20th century by J. L. Moreno. Moreno undergirded psychodrama with deep philosophical convictions about the nature of space, time, reality, and the cosmos [24]. Psychodrama has been used by thousands of practitioners because of its philosophical depth [25]. He believed that psychodrama tapped into the most significant aspects of man's existence, and that was the reason he used it: "A therapeutic method which does not concern itself with these enormous cosmic implications, with man's very destiny, is incomplete and inadequate” ([24], p. 11). The human person, he believed, is a very significant being: 
"Man is a cosmic man, not only a social man or an individual man” ([24], p. 10). As a form of therapy, psychodrama taps into the deepest part of one's soul: "Psychodrama is, as the word implies, a dramatizing of psyche, a kind of soul theatre” ([26], p. 562). The individual person is given a stage for her life, in order that she may see it in a clearer way, and that she may learn to abandon 'old scripts' and rehearse new and more authentic scripts for life [27]. The overlap between the individual focus of psychodrama and the universal focus of the theodrama is clear. Psychodrama focuses on one actor's role in the theodrama by making it explicit to one's attention. This process is facilitated by five essential components: a stage, a protagonist, auxillary egos, a group, and a director.

First, a stage is used. The stage may be as complex as the large three-tiered version with balcony and lights used by Moreno, but any place will suit as long as it can fit the number of people involved. The stage, as a term in theatre, is where the drama is enacted, the environment or world in which the actors perform their role. The stage is a space that enables a person to "be and to act himself in an environment which is modeled after that in which he lives” ([24], pp. 6-7). In psychodrama, the stage is where a person's environment is imaginatively reconstructed and where a vignette of his or her life's drama is performed. For example, a person may imagine the stage as his office. If available props are at hand, the stage may be furnished to resemble the office with a chair, desk, etc. With the stage set, the person then plays out a scene from his life in that environment.

Second, the protagonist is the person receiving the primary focus in the psychodrama. The protagonist is chosen from among the group members as a representative. This person is usually chosen because his present issue or problem is one with which other group members identify or one which they share in common. The environment of the stage is the protagonist's environment, and the action performed concerns the protagonist. The protagonist will enact situations from his past and present, and he may also enact situations in view of the future.

Third, auxiliary egos are other members of the group who join the action centered around the protagonist. They may serve as other people in the protagonist's situation (spouse, boss, father) or as parts of the protagonist's self (little boy). The protagonist chooses group members to play these parts; they are given the needed information to play their role, and then they join the action.

Fourth, the group itself is a basic instrument of psychodrama. Although psychodrama may be performed with just a protagonist and one other (director), it is usually done as a kind of group therapy. I will assume that the group aspect is essential to psychodrama, since the importance of finding one's identity within a corporate body has been emphasized. The group chooses the protagonist and assists by becoming auxiliary egos. At the end of a session, the group offers support to the protagonist and shares perspectives about the experience.

Fifth, the director guides the entire process. The director assists in selecting the protagonist and auxiliary egos. He guides the protagonist in setting up the scene and arranging objects or characters on the stage. The director leads the protagonist through the action with directives about what to do, observations about the scene, and questions that lead the protagonist onward in the drama. The director begins the process and guides it to the end. His main task is to facilitate the protagonist's action into an opportunity for change and growth.

These five components allow psychodrama to give a person an opportunity for change and to be liberated out of a lurch in life by rehearsing new possible ways of living. Psychodrama provides a person a space to 'rehearse life.' Before ever coming to psychodrama, people already act out rehearsed 
ways of living according to the scripts they have accepted or fashioned for themselves; psychodrama offers a person a 'new stage' with a different audience [27]. For example, a father may have taken on certain scripts that inform the way he acts towards his children at home. One of the scenes might proceed like this:

Dad walks into the living room and sees his three-year-old daughter jumping off the couch unto a pile of pillows. He furrows his brow and says abruptly, "Be careful! You could hurt yourself.”

Daughter continues to play, but goes to another room with a toy.

Dad mutters, "What a mess this place is. You'd think it was a jungle gym instead of a living room!"

In a session of psychodrama, the director might help the father reenact this scene with his daughter by asking him to reverse the roles: "If you were your daughter, what would you be receiving from Dad's words and behavior in this scene?” Reenacting the scene in the role of his daughter, it might then dawn on him that, if he were her, he would feel surprised and maybe even frightened by Dad's sudden outburst. He might also internalize a line Dad often says_- "Be careful!”- and take on that anxiety as his own. Role reversal is a powerful tool in psychodrama, because it places the protagonist in another person's shoes, providing a new vantage point from which to behold his actual ways of living [28]. Psychodrama can do more, however, by empowering one to break out of what is actual into what is possible. Having been made aware of the script one plays out before his daughter and its effects upon her, the father has the vision and motivation to discard this script and start rehearsing a new one. At this point, psychodrama offers the protagonist "resources never before dreamed of, new capacities for understanding of himself and others, new bravery and new warmth. He is helped to be aware where once his eyes were shut, to speak where once his tongue was stilled, to live where once he had only existed" ([29], p. 235). Enter the theodrama.

Actually, the theodrama has been here all along because it encompasses the swath of God's drama in the world, and that includes the role that each particular person's life plays within it. Psychodrama explicates an individual's role as an actor in the universal theodrama. And, bringing this relationship to bear on self-deception, psychodrama reveals the latent forms of mendacity that hinder one from fitting performance in the theodrama. Psychodrama can prove to be a powerful aid in fulfilling one's theodramatic role.

Psychodrama enables one to become conscious of self-deception by reenacting and rehearsing everyday actions. Rehearsal is a necessary part of renewing one's theodramatic imagination and overcoming self-deception:

To become explicitly conscious of one's situation [...] demands that one rehearse what one is doing. We seldom feel it necessary to spell out our engagements in any detail, however [...] There are many things we do every day — dressing, eating, playing with our children or talking with our spouses—-that can be carried on without bothering to delineate how they may contribute to an overall life-plan. We seldom "spell out" what we are doing unless we are prodded to do so ([29], p. 102).

Psychodrama prods. It brings one face-to-face with the way one lives, revealing the "small story" of our day-to-day existence [30].

A person's small story, if under the auspices of self-deception, is antithetical to fitting performance in the theodrama. To get out of the small, distorted story one must locate himself in the larger, true story of God. That story is the theodrama-specifically, it is the Gospel of Jesus Christ, who entered 
the stage of the world as a human actor and performed God's script in a way that frees one to take up the role he had lost because of sin. The larger drama with which psychodrama begs one to identify is the Christodrama. Christ's drama — his life, death, resurrection, and ascension —is the drama a Christian must fit his life within in order to be rid of his old false self and take on a new self:

Christians claim to find the skill to confess the evil that we do in the history of Jesus Christ. It is a history of suffering and death that must be made our own if we are to mine its significance. The saints formed by this story testify to its efficacy in purging the self of all deception as it forces the acceptance of a new self mirrored in the cross" ([30], p. 114).

Just as a self-deceived imagination hinders one from living out his role authentically, the imagination that is oriented to Jesus Christ can free one to perform like him.

Let us make the points of the last several paragraphs very explicit. First, psychodrama serves to uncover one's actual behavior. Second, psychodrama can also reveal possibilities for change. Third, when the drama of one's life (psychodrama) is oriented to the drama of Christ (theodrama), one can rehearse new ways for living that break out of one's old identity (small story, old script, etc.) and that correspond to who one is in Christ. From these points, two conclusions follow about the relationship between psychodrama and theodrama.

\section{Integrating Psychodrama into the Theodrama}

From a Christian psychology perspective, theodrama requires psychodrama. If a person wants to perform in the theodrama, then some form of psychodrama must be used, even if it is simply 'performed' in the context of two friends talking openly about their lives. Psychodrama is rehearsal, and one must rehearse if he is to break the spells of self-deception that block his participation in the theodrama. Theodrama cannot be approached merely as a cognitive, affective, or volitional exercise. For a Christian, it is not enough to think about the Gospel, nor to feel emotions about it, nor to will certain actions in response to it, for all these can be forms of self-deception. Theodrama, if not integrated into oneself, is just an impotent idea. One may study it and articulate it as doctrine, yet never apply its meaning to life. One can despise injustice in the world, yet all the while employing his emotions to mask his own lack of justice. One can even take action by tending to the 'things of God' or ministering to the needs of others, while neglecting to do what God says is most needful for him. If an individualis to derive any benefit from the theodrama, then he must apply it to himself. Psychodrama applies the universality of the theodrama to the particularity of the individual. I am not saying that psychodrama - as method of psychotherapy — is the only instrument for appropriating theodrama. There are other methods of rehearsal that the imagination may use. What is most essential to the appropriation of theodrama is some form of imaginative reconstruction (i.e., rehearsal). In that sense, psychodrama is necessary for an individual's performance of the theodrama.

Second, from a Christian psychology perspective, psychodrama requires theodrama. Psychodrama without theodrama is a play without the right script. Some advocates of psychodrama miss this point. They believe that once psychodrama has exposed a person's false scripts, the next step is to start writing a new one, or even to be done with scripts altogether [29]. Psychodrama, some maintain, does not try to give one anything other than what the person can imagine: "For in a very real sense 
psychodrama does not give to an individual anything that is foreign to himself. It only helps him to discover within himself new resources never before dreamed of” ([29], p. 235). The individual, however, must look outside the self, transcending his own limited vision of reality. In order to experience reality one needs to expose his narrow and distorted view of the world: "To uncover our deceptions and to recognize the lie in sin which leads to pride and moral obtuseness will not of itself deliver us. And yet, that is the first step. St. Paul would not have known Christ as Saviour had he not been confronted by Him as Judge” ([31], p. 77). To make the leap from falsehood to truth, however, we need to transcend ourselves [32]. For example, Stephen Weisz, a therapist working with psychotic patients, was given the task of performing a nativity play for his mental health facility [33]. He discovered that the patients who performed in the play experienced a temporary escape from their psychoses by taking on exterior roles that accorded with a different script. Psychodrama provides the first step to a larger vision, outside oneself. Of course, it is counter-productive to simply accept some other script, either from society or of one’s making, which only serves to continue one's self-deception. Ironically, psychodrama and every other therapy that aims to combat self-deception is liable to replace one form of self-deception for another: "Each [form of therapy] will cure you of self-deception, open your eyes - if you will step into his circle. Cautious skeptics, however, may worry that this therapeutic circle with entangle them in some new devices with which to deceive themselves” ([14], p. 112). What is needed is the right script, the script that corresponds with reality-the script of the theodrama.

The theodrama as script orients the protagonist's action in a psychodrama around the action of Christ. By virtue of Christ's life as a human being, the protagonist can claim union with Christ and appropriate all that belongs to Christ's life to himself. Thus, when a father sees the part of himself that shoves anxiety unto his daughter, he can consider it crucified with Christ. And when he looks for the strength to continually 'put off' that aspect of his self and replace it with new ways of living, he can find that strength in Christ's resurrection and ascension. Donning the new self in Christ, he can rehearse new ways of living towards his daughter and others in his life. The action of Christ can be realized in one's own experience.

When psychodrama and theodrama are integrated, the individual is given the opportunity to encounter God, and thereby to begin to reconstruct his imagination and perform a new role in life. It is through a meeting with the God of the theodrama that self-deception is traded for self-realization. In Leo Tolstoy’s “The Death of Ivan Illyich”, Ivan is a man who is self-deceived, having taken on the script offered by his upper-class society. He is incapable of truly loving others in his life because he is so absorbed in maintaining the false self he has adopted. The moment of truth in Ivan's life comes when he not only realizes his self-deception but transcends it through an encounter with God:

Ivan's break-through is neither simply a psychological illumination of self-understanding nor only a moral conversion toward truthfulness and love. It is also an epiphany, a moment in which he feels God's understanding both in the cognitive sense, in which Ivan knows that God comprehends him in his depths, and, more importantly, in the affective sense, in which Ivan feels that God accepts, loves, and forgives him ([34], p. 126).

Christianity maintains that God encounters people through his Son, Jesus Christ. When psychodrama is integrated with theodrama, those involved should make it their aim to come face-to-face with Jesus. 


\section{Conclusions}

To conclude, let us consider how combating self-deception with psychodrama must be counterbalanced by contemplation. Psychodrama has many great advantages; one that we have barely touched is its group aspect, which can be seen as a manifestation of Christ's body building itself up in love (Eph. 4:16). Notwithstanding the necessity of this corporate dynamic, the internalization of one's identity in the theodrama must also happen alone with God in silence and contemplation. The spiritual practice of contemplation is rooted in the acknowledgement that God alone can give one his identity [22]. One does not receive his identity wholly from others, although they can support its construction. Christian psychology assumes that one cannot achieve full self-knowledge apart from God. Kierkegaard believed that self-presence is a task, not an achievement, because self-presence depends on God and not oneself: "In its self-relation the self is not posited as the ground of certainty, the criterion of truth, the self-sufficient and absolute mode of being, in short, the center" ([32], p. 171). God alone can give a person his identity; God is the ultimate director of one's psychodrama. A human psychodramatist, counselor, or friend may only suggest creative possibilities for self-realization. If they go beyond suggestions to controlling, they may seduce another into a false script of their own making that leads to yet another false self. One Christian writer has said that people need God to break their images of themselves, for God alone is the great iconoclast - the one who destroys false images [35]. Contemplation responds to God's summons to rehearse life coram deo, in the presence of God. Prayer is a kind of rehearsal, for it offers up oneself to God, who mysteriously unites one to Christ through the Spirit, by whom Christians cry out to the Father as sons. Teachers in the Christian tradition have long held that the passive activity of prayer is more important than anything else one can think, feel, or do in the fight against self-deception, for in prayer one calls "upon the one who knows our hearts better than we do" ([7], p. 188).

To bring this discussion forward into greater fruitfulness, I suggest we take up the subject of self-deception into other modes of rehearsal. Theodramatic rehearsal is one weapon we can utilize against the lure of the lying self, but there are others. Men of action will claim every one.

\section{Acknowledgements}

I was first introduced to psychodrama through the Cross Ministry Group and its founder, Bob Hudson, who has implemented the use of psychodrama in a profoundly Christian way. This paper has been an attempt, in part, to explain how the use of psychodrama in such ministries is not only permissible and beneficial for Christian soul care providers but is also commensurable with Christian doctrine and practice. The task of Christian psychology, as I understand it, is to do this kind of workthe work of strong and explicit integration [2]. My doctoral advisor and mentor, Eric L. Johnson, has modeled the task of Christian psychology in his works, and so I have attempted to follow his lead.

\section{Conflict of Interest}

The author declares no conflict of interest. 


\section{References}

1. William Goldman. The Princess Bride: S. Morgenstern's Classic Tale of True Love and High Adventure. Orlando: Harcourt Inc., 2007.

2. Eric Johnson. Foundations for Soul Care: A Christian Psychology Proposal. Downers Grove: InterVarsity Press, 2007.

3. Kevin Vanhoozer. The Drama of Doctrine: A Canonical Linguistic Approach to Christian Doctrine. Louisville: Westminster John Knox Press, 2005.

4. Klyne Snodgrass. Stories with Intent: A Comprehensive Guide to the Parables of Jesus. Grand Rapids, Michigan: William B. Eerdmans Publishing Company, 2008.

5. Kevin Vanhoozer. "Forming the Performers: How Christians can Use Canon Sense to Bring Us to Our (Theodramatic) Senses.” Edification: The Transdisciplinary Journal Of Christian Psychology 4, no. 1 (2010): 5-16.

6. Michael D. Williams. "Theology as Witness: Reading Scripture in a New Era of Evangelical Thought. Part II: Kevin Vanhoozer and The Drama Of Doctrine.” Presbyterion 37, no. 1 (2011): 16-30.

7. Eric L. Johnson, and Christina Sellers Burroughs. "Protecting One’s Soul: A Christian Inquiry into Defensive Activity.” Journal of Psychology and Theology 28, no. 3 (2000): 175-89.

8. Bruce S. Alton. “The Morality of Self-Deception.” In Annual of the Society of Christian Ethics 1985. Vancouver: Georgetown University Press, 1985, pp. 123-55.

9. John Charles Knapp. "Pride and the Power of Self-Deception.” Journal for Preachers 25, no. 2 (2002): 14-20.

10. Pieter J. J. Botha. "Theology, Rationality and Truth-Claims: Metatheoretical Reflections on Self-Deception.” Religion and Theology 12, no. 2 (2005): 97-128.

11. Merold Westphal. “Orthodoxy and Inattention.” Reformed Journal 30, no. 1 (1980): 13-15.

12. Ava Chamberlain. "Self-Deception as a Theological Problem in Jonathan Edwards' 'Treatise Concerning the Religious Affections'.” Church History 63, no. 4 (1994): 541-56.

13. Dietrich Von Hildebrand. The Heart: An Analysis of Human and Divine Affectivity. South Bend: St. Augustine's Press, 2007.

14. Stephen Crites. "The Aesthetics of Self-Deception.” Soundings 62, no. 2 (1979): 107-29.

15. Peter Sedgwick. "Redemption and Self-Deception.” Theology 111, no. 864 (2008): 403-11.

16. Samuel Taylor Coleridge. The Collected Works of Samuel Taylor Coleridge: Biographia Literaria. Edited by James Engell and Jackson Bate. Princeton: Princeton University Press, 1983.

17. J.R.R. Tolkien. “On Fairy Stories.” In Tree and Leaf. London: Harper Collins Publishers, 2001.

18. William Wood. “Axiology, Self-Deception, and Moral Wrongdoing in Blaise Pascal's Pensées.” Journal of Religious Ethics 37, no. 2 (2009): 355-84.

19. Robert Roberts. Spiritual Emotions: A Psychology of Christian Virtues. Cambridge: William B. Eerdmans Publishing Company, 2007.

20. Susan Harter. The Construction of the Self: A Developmental Perspective. New York: The Guilford Press, 1999.

21. Stephen W. Sykes. “The Grammar of Narrative and Making Sense of Life.” Journal Anglican Theological Review 67, no. 2 (1985): 117-26. 
22. Thomas Merton. Seeds of Contemplation. New York: New Directions, 1949.

23. Charles Roy Stinnette. "The Use of Drama as a Means of Self-Insight.” Religious Education 68, no. 6 (1973): 708-14.

24. Jacob L. Moreno. The Essential Moreno: Writings on Psychodrama, Group Method, and Spontaneity. Edited by Jonathan Fox. New York: Springer Publishing Company, 1987.

25. Peter D. Mendelson. "Sociometry as a Life Philosophy.” Group Psychotherapy, Pyschodrama, and Sociometry 30 (1977): 70-85.

26. Peter A. Pitzele. "The Psychodrama of the Bible: Mirror and Window of Soul." Religious Education 86, no. 4 (1991): 562-70.

27. Jared Rardin. “The Rites of Resistance: Image and Drama in Pastoral Psychotherapy.” Journal of Pastoral Care 33, no. 3 (1979): 175-84.

28. Paul E. Johnson, James M. Enneis, and Jacob L. Moreno. "Psychodrama and role-playing." Pastoral Psychology 6, no. 53 (1955): 54-57.

29. Janet Haas. "Psychodrama: Rehearsal for Reality.” Journal of Pastoral Care 12, no. 4 (1958): 230-35.

30. David B. Burrell, and Stanley Hauerwas. "Self-Deception and Autobiography: Theological and Ethical Reflections on Speer's Inside the Third Reich.” Journal of Religious Ethics 2, Spring 1974, 99-117.

31. Harold Roberts. “Doctrine of Man, Part 6: Self-Deception.” Expository Times 61, no. 3 (1949): 74-77.

32. Merold Westphal. "Religious Experience as Self-Transcendence and Self-Deception.” Faith and Philosophy 9, no. 2 (1992): 168-92.

33. Stephen Ranken Weisz. “The Use of Drama in Therapy with Psychotic Patients.” Journal of Pastoral Care 28, no. 2 (1974): 134-35.

34. Stephen J. Pope. "Compassion and Self-Deception: The Unity of Love and Truthfulness in Leo Tolstoy’s “The Death of Ivan Ilyich.” Annual of the Society of Christian Ethics 19 (1999): 115-29.

35. C. S. Lewis. A Grief Observed. New York: Harper Collins, 1989.

(C) 2014 by the author; licensee MDPI, Basel, Switzerland. This article is an open access article distributed under the terms and conditions of the Creative Commons Attribution license (http://creativecommons.org/licenses/by/3.0/). 